\title{
„Niewolnicy świętego Mikołaja”. Eskalacja debaty społecznej wokół holenderskiej tradycji
}

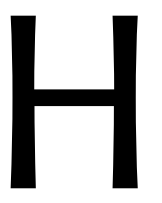

olandia uchodzi często za kraj liberalny i pozbawiony uprzedzeń rasowych, kulturowych oraz religijnych. Zdaje się wyprzedzać inne kraje - także w skali światowej - w procesie tworzenia wolnego i otwartego społeczeństwa. Ten stereotypowy obraz traci swoją ostrość, kiedy przybysz z zewnątrz ma szansę uważnie i długotrwale obserwować mentalność oraz poglądy Holendrów, wtopiony w mozaikę tej wieloetnicznej społeczności'. Jej wewnętrzne tarcia ujawniają się w momentach, w których proces globalizacji staje się zagrożeniem dla ,,staroholenderskich” tradycji.

Uroczystość Sinterklaasa (świętego Mikołaja) obchodzona jest w Holandii 5 grudnia i stanowi jedno z najważniejszych wydarzeń w roku obrzędowym. W miastach holenderskich - już od drugiej połowy listopada - organizowane są widowiska uliczne będące inscenizacją uroczystego przybycia świętego biskupa. W tradycji holenderskiej postać świętego Mikołaja upamiętnia katolickiego biskupa żyjącego w IV wieku naszej ery w tureckiej Myrze. Tradycja głosi dalej, iż święty zamieszkuje obecnie Hiszpanię, z której przybywa drogą morską. Na holenderską ziemię wjeżdża na białym koniu. Towarzyszą mu liczni pomocnicy, tzw. Zwarte Pieten (Czarni Piotrowie).

Wspomniani pomocnicy świętego Mikołaja już od kilku dziesięcioleci wywołują kontrowersje i stają się przedmiotem powracających każdego roku konfliktów społecznych.

\footnotetext{
${ }^{1}$ Około $20 \%$ obywateli holenderskich zaliczanych jest do allochtonów (osób nieurodzonych w Holandii lub będących dzieckiem rodzica urodzonego poza jej granicami).
} 
W roku 2013 miała miejsce najgorętsza dotąd debata społeczna, która stanowi przedmiot analizy niniejszego artykułu.

\section{Inscenizacja porządku społecznego doby kolonializmu?}

Podczas ulicznych widowisk Zwarte Pieten odgrywani są przez osoby pochodzenia europejskiego. Noszą kolorowe kostiumy przypominające strój klowna, na który składa się bluza z długimi rękawami, szerokie spodnie sięgające za kolano, rajstopy oraz nakrycie głowy w formie beretu. Najbardziej charakterystyczny jest ich ,namalowany” kolor skóry - czarny lub brązowy - nadający im cechy negroidalne, podkreślone dodatkowo poprzez pogrubione szminką usta oraz czarne peruki afro. Uszy pomocników zdobią zazwyczaj złote kolczyki².

Wygląd postaci Zwarte Pieten jest najważniejszą, ale nie jedyną przyczyną konfliktu. Równie istotna jest kwestia hierarchii istniejącej pomiędzy białym biskupem oraz czarnymi sługami, określanymi w języku holenderskim słowem knecht (sługa, parobek), które semantycznie zbliżone jest do ,niewolnika”.

Postać Zwarte Pieten wprowadzona została do tradycji świętego Mikołaja w połowie XIX wieku i również dlatego odczytywana jest jako wyraz ówczesnych poglądów w kwestii kolonializmu i niewolnictwa ${ }^{3}$. Kontekst historyczny jest jednym z najczęstszych argumentów wysuwanych przez przeciwników tej tradycji, o których pisze holenderska prasa. Równie znaczące są negatywne emocje, jakie budzi ona współcześnie pośród członków mniejszości etnicznych będących obywatelami państwa holenderskiego.

\section{Stan badań}

Opisywany przypadek wydaje się wyjątkowy z jednego, lecz istotnego powodu. W dotychczasowym dyskursie poświęconym funkcjonowaniu mniejszości etnicznych w społeczeństwach zachodnioeuropejskich skupiano się przede wszystkim na ich prawach (oraz ich granicach) do zachowania własnej kultury i wartości. Z drugiej zaś strony dostrzegano konieczność procesu integracyjnego, a zatem poznanie i zaakceptowanie podstawowych wartości kultury zachodnioeuropejskiej przez napływających imigrantów. W tym przypadku

\footnotetext{
${ }^{2}$ W roku 2013 w niektórych miejscach zrezygnowano już z tego elementu.

${ }^{3}$ Postaci Zwarte Pieten do tradycji świętego Mikołaja wprowadził w roku 1850 pracujący w Amsterdamie nauczyciel oraz autor książek dla dzieci Jan Schenkman.
} 
natomiast to tradycja większości znajduje się w „sytuacji zagrożenia”. Nie od mniejszości, ale właśnie od większości wymaga się dopasowania do sytuacji społeczeństwa wielokulturowego, co oznacza rezygnację z tradycji lub przynajmniej jej elementów.

Historię tradycji świętego Mikołaja, obejmującą jej narodziny oraz przemiany, opisano wielokrotnie w holenderskiej literaturze naukowej oraz popularnonaukowej (Ghesquiere, 1989; Wouters, 2008; Boer-Dirks, 2009; Helsloot, 2009). W literaturze niderlandzkojęzycznej wiele uwagi poświęcono postaci Sinterklaasa, społecznej percepcji święta oraz jego roli na tle innych tradycji holenderskich (Leer, 1995; Renterghem, 1996; Helsloot, 2001; Helsloot, 2003; Smit, 2005). Zainteresowania niektórych etnologów skupiały się szczególnie wokół postaci Zwarte Pieten (Boer-Dirks, 1993; Langeler, 1994; Booy, 2005; Booy, 2008; Helsloot, 2003, s. 93-117). Badano przede wszystkim ich kulturowe pochodzenie, ewolucje ich wyglądu oraz zachowania, a także zmiany w odbiorze społecznym w ciągu kolejnych dziesięcioleci (Helsloot, 2005). Podejmowano próby metarefleksji na temat kontrowersji powstających wokół tych postaci. W odniesieniu do obecnie trwającej dyskusji Holenderscy etnolodzy zwracają uwagę na swoją pozycję „,uczestnika”, która utrudnia zajęcie obiektywnego stanowiska wymaganego od badacza (Helsloot, 2009, s. 83).

Przedmiotem analizy jest debata, która miała miejsce w holenderskich mediach i prasie w okresie październik-grudzień 2013 roku. Mieści się ona w szerokim kontekście rozważań na temat funkcjonowania społeczeństw wieloetnicznych. Kwestii tej poświęcone zostało bardzo wiele prac socjologicznych oraz antropologicznych, zwłaszcza w odniesieniu do Stanów Zjednoczonych oraz państw Europy Zachodniej. Zagadnienie to omawiano także w perspektywie historycznej, analizując skutki przyjętej w XX wieku polityki wobec imigrantów i tworzenia się struktur mniejszościowych (mowa tu o ideach asymilacji, społeczeństwa wielokulturowego oraz pluralizmu). Stawiano pytania o interakcje kultur w społeczeństwie wieloetnicznym, zwłaszcza w sytuacji istnienia konkurencyjnych systemów wartości (Jacher, 2007, s. 93-99). W związku z procesami migracyjnymi, nauka stawia również wiele pytań o tworzenie odpowiedniego systemu edukacji, który wspomagałby kreowanie właściwych postaw społecznych (Bartz, 1997; Smolicz, 1990, s. 101-134). Naukowcy zwracali również uwagę na redefinicje pojęcia etniczności we współczesnych społeczeństwach wielokulturowych (Lewowicki, Grodzka-Mazur, Gajdzica, 2003, s. 38). W ramach podejmowanych rozważań - także w literaturze polskiej - pojawia się również sytuacja państwa holenderskiego (Nikitorowicz, 2010, s. 237-238). Z powyższymi problemami wiąże się bezpośrednio zjawisko globalizacji oraz współczesnych form komunikacji i ich znaczenia w budowaniu dialogu międzykulturowego (Kuciński, 2011, s. 199-216). 
Artykuł powstał w oparciu o analizę treści medialnej (telewizja, Internet) oraz prasy o zasięgu ogólnonarodowym, pełniących funkcje forów społecznych. Takie ograniczenie zakresu źródłowego ukierunkowane jest na ukazanie zjawiska właśnie w jego świetle, jak również podkreślenie roli mediów w tworzeniu oraz dalszej eskalacji nowoczesnego dyskursu społecznego ${ }^{4}$. Dyskurs rozumiany jest tutaj jako zdarzenie komunikacyjne, odbywające się w określonym czasie i miejscu, o charakterze językowym i pozajęzykowym (inne znaczące działania aktorów społecznych). Każdy uczestnik dyskursu ma istotny, ale nie decydujący wpływ na jego konstruowanie (Trutkowski, 2004, s.10).

Kolejna odsłona debaty społecznej, która także nastąpiła w roku 2013, zostanie poddana swoistej metarefleksji. Jej cechą jest neutralność, co oznacza, że autorka nie opowiada się po żadnej ze stron konfliktu. Niniejszy tekst jest próbą odpowiedzi na pytanie o przyczynę tak silnej eskalacji społecznej debaty. Analiza skupiać się będzie wokół trzech głównych zagadnień: komunikacji społecznej w realiach wielokulturowych, tożsamości i identyfikacji etnicznej i narodowej oraz roli mediów w powstaniu i rozwoju debaty społecznej. W zakresie komunikacji należy odpowiedzieć na następujące pytania: Czego dowiadujemy się - na podstawie toczącego się sporu - o charakterze komunikacji w wielokulturowym społeczeństwie holenderskim? Jak rozumiane są podstawowe pojęcia używane w debacie, takie jak: demokracja, rasizm oraz tradycja? Jaki jest ton debaty i jak oceniają ją sami Holendrzy (autorefleksja nad kondycją społeczeństwa oraz tożsamości narodowej)? Analizując pojęcie tożsamości, należy zastanowić się nad sposobem, w jaki w zaistniałym konflikcie definiowane jest bycie Holendrem? Jakie podziały społecznokulturowe ujawniły się lub nasiliły w wyniku toczącej się debaty? Kto postrzegany jest jako „prawowity Holender”? Jak społeczeństwo holenderskie postrzega siebie w kontekście międzynarodowym? W trzeciej części rozważań poruszona zostanie rola mediów w eskalacji problemu oraz wzmacnianiu zjawiska agresji.

\section{Casus belli debaty}

Spór wokół tradycji świętego Mikołaja, który powrócił po raz kolejny jesienią 2013 roku, nie był zjawiskiem nowym, ale tym razem przybrał najgwałtowniejszą formę. Verene Shepherd - pochodząca z Jamajki profesorka uniwersytetu West Indies, działająca w ramach ONZ, zgłosiła sprawę Zwarte Pieten do Rady Praw Człowieka w Genewie. W związku

\footnotetext{
${ }^{4}$ Niemniej jednak analiza treści medialnej została skonfrontowana z bezpośrednią obserwacją nastrojów panujących w tym czasie w Holandii (obserwacja uczestnicząca oraz wywiad swobodny).
} 
z tym powołano specjalną komisję, której zadaniem jest zbadanie holenderskiej tradycji świętego Mikołaja. Działania Shepherd wywołały w Holandii pierwszą falę dyskusji. Zarzucano jej przede wszystkim skrajną lewicowość, nieznajomość kultury holenderskiej oraz włączenie sprawy dotyczącej Zwarte Pieten do szerszej kampanii mającej na celu uzyskanie możliwie największych odszkodowań dla dawnych kolonii ${ }^{5}$. Pojawił się również argument, że sprawa holenderskiej tradycji jest trywialna w porównaniu z ważniejszymi problemami i konfliktami w skali światowej ${ }^{6}$. Wpływ na rozwój toczącej się debaty miał także pochodzący z Antyli artysta Quinsy Gario, który jeszcze w roku 2011 w trakcie obchodów święta w Amsterdamie pojawił się w T-shircie z napisem Zwarte Piet is racisme (Czarny Piotr to rasizm) ${ }^{7}$. Powodem jego wystąpienia była nieprzyjemna sytuacja, jaka spotkała jego matkę, porównaną przez przypadkową osobę do postaci Zwarte Piet. Gario został agresywnie zaatakowany przez funkcjonariuszy policji, mimo że jego akcja miała charakter manifestacji pokojowej lub - jak sam twórca performance podkreślił - działania artystycznego ${ }^{8}$. Wydarzenie to nadało jego osobie wizerunek męczennika, a podnoszona przez niego sprawa musiała być ponownie poddana społecznej refleksji. Jego rola nie traciła na znaczeniu w kolejnych latach.

\section{Komunikacja}

W niniejszej części omówione zostaną aspekty komunikacji w toczącym się konflikcie. Zastanowić się zatem należy nad jej charakterem, a przede wszystkim nad tym, czy zaistniała prawdziwa dyskusja polegająca na wsłuchiwaniu się w głosy innych i wyrażaniu opinii będących kontrargumentami w stosunku do poglądów strony przeciwnej?

Teoria komunikacji kulturowej zakłada bowiem poznawczy charakter dyskusji, wymagający od uczestników wzajemnej interakcji. Jeśli zaistnieje intencja komunikowania przez nadawcę, ale nie będzie jej odpowiadała intencja odbiorcy, proces poznawczy nie będzie miał miejsca (Borden, 1996, s. 59-61). Przyglądając się komunikacji zwolenników i przeciwników postaci Zwarte Pieten, nie zawsze odnajdziemy w niej cechy prawdziwej dyskusji, argumenty jednej strony bardzo często pozostawały bowiem bez odpowiedzi drugiej. W języku holenderskim używano określeń dyskusja oraz debata. Należy je rozumieć jako sumę wielorakich głosów płynących z różnych środowisk, a słyszanych dzięki

\footnotetext{
${ }^{5}$ Rutte moet traditie Zwarte Pieten stoppen, „Reformatorisch Dagblad”, 23 X 2013.

${ }^{6}$ VN die zich met Sint en Piet bemoeien? Onzin!, "AD/Algemeen Dagblad”, 21 X 2013.

7 Niet-Zwarte Piet, "de Volkskrant", 19 X 2013.

${ }^{8}$ Piet was man van aanzien, gelijkwaardig aan sint, "Het Parool", 13 XI 2013.
} 
mediom i prasie. Debata oznacza w tym przypadku bardziej wyraz konfliktu niż drogę do ewentualnego porozumienia. Środowiska naukowe postulowały natomiast dialog jako jedyny możliwy sposób na rozwiązanie zaistniałego sporu ${ }^{9}$. Stosunkowo niewielka grupa biorąca udział w dyskusji wykazała się postawą, która określana jest w teorii komunikacji jako dialogowa (Winiarski, 2000, s. 123). Nie zaistniało bowiem wzajemne otwarcie się na siebie, które umożliwiłoby uzyskanie całkowitego kompromisu, możliwego do zaakceptowania przez wszystkie strony.

Wyrazem postawy ugodowej były jednak zmiany, jakie wprowadzono w niektórych miastach (zwłaszcza w Amsterdamie) w wyglądzie postaci Zwarte Pieten (rezygnacja z pogrubionych ust oraz złotych kolczyków w uszach). Pojawiły się różne propozycje rozwiązania problemu, których akceptacja mogłaby umożliwić w przyszłości „,zawarcie porozumienia”. Skrajna postawa zwolenników Zwarte Pieten zakłada zachowanie tradycji w jej aktualnej formie. Radykalni przeciwnicy postulowali natomiast całkowite zaniechanie obchodów uroczystości Sinterklaasa. Wyrazem postawy ugodowej jest akceptacja zmian w wyglądzie Zwarte Pieten, które miałyby jednak następować stopniowo, nie zaś gwałtownie. Pojawiła się również idea wprowadzenia kolorowych lub białych postaci, które miałyby występować obok czarnych lub też zupełnie je zastąpićn ${ }^{10}$.

W debacie odwoływano się do określonej grupy pojęć, nadając im różnorodne, a często nawet przeciwstawne znaczenie. Demokracja na przykład definiowana była w jednej z wypowiedzi prasowych jako konieczność dostosowania się do poglądów większości ${ }^{11}$, w innej zaś jej głównym wyznacznikiem miał być obowiązek liczenia się z uczuciami innych, nawet jeśli należą oni do mniejszości ${ }^{12}$.

Powracającym częstokroć w debacie pojęciem był rasizm, o który przede wszystkim oskarżano się wzajemnie ${ }^{13}$. Zwolennicy istniejącej tradycji negowali zupełnie obecność elementów rasistowskich w obchodach świętego Mikołaja, argumentując, że jest to jedynie dziecięce święto ${ }^{14}$. Postawę rasistowską dostrzegano w upartym dążeniu do zachowania istniejącej formy tradycji, pisząc na przykład: Czarny ból jest mniej wart niż biała przyjemność. I to, moi drodzy, jest czysty rasizm ${ }^{15}$. Komentowano w ten sposób

\footnotetext{
9 Stem van de redelijkheid; Oproep tot dialoog, „De Telegraaf”, 22 X 2013.

10 Zwarte Piet verbindt niet meer, "Het Parool", 11 XI 2013, Trommel Witte Pieten op, "de Volkskrant", 18 XI 2013, Is Nederland gek geworden?, "De Telegraaf" 26 X 2013.

11 Tegengeluid uit buurt van slavenhandelaars, "AD/Algemeen Dagblad", 24 X 2013.

12 Democratie is rekening met elkaar houden, "Metro (NL)", 18 XI 2013.

13 Intocht Sinterklaas extra beveiligd in Rotterdam, "Metro", 15 XI 2013, Witte Piet was in 1968 ook al een stap te ver, "de Volkskrant", 16 XI 2013, Kleur, "AD/Algemeen Dagblad", 16 XI 2013, Discriminatie zal altijd blijven, "Het Parool”, 18 XI 2013.

${ }^{14} \mathrm{Nu}$ ligt de intolerantie tenminste op straat, "de Volkskrant", 25 X 2013.

15 Zwarte pijn en wit plezier, "de Volkskrant", 11 X 2013.
} 
przedkładanie znaczenia folklorystycznej zabawy nad uczucia mniejszości etnicznych. Użyte tutaj określenia barw, odnoszące się w oczywisty sposób do koloru skóry, nabierają wartościującego wydźwięku. Podkreślają wyraźnie istnienie odrębnych grup w społeczeństwie, przynależność do których wyznaczana jest pochodzeniem etnicznym. Bardzo często w tej dyskusji głosy przeciwko rasizmowi - zamiast zwalczać - uwypuklały istnienie społecznych nierówności.

W sposób niejednolity rozumiane było pojęcie tradycji oraz rządzących nią reguł. Przedstawiciele świata nauki podkreślali, że tradycja nie jest zjawiskiem niezmiennym, a jej nieodłączną cechą jest przeobrażanie się i ewolucja. Warto przytoczyć chociażby słowa Ineke Strouken (Holenderskie Centrum Kultury Ludowej i Dziedzictwa Niematerialnego w Utrechcie), starającej się przekonać zwolenników Zwarte Pieten, że zmiana w wyglądzie tych postaci byłaby czymś naturalnym: Tradycje są z definicji dynamiczne. Dopasowują się nieustannie do ducha czasów ${ }^{16}$. Inaczej pojęcie tradycji rozumieli czytelnicy prasy codziennej, wyrażający swoje opinie w formie listów pisanych do redakcji: [...] esencją tradycji jest właśnie to, że ona się nie zmienia, ale jako stały i pewny znak utrzymuje się niezmiennie, jako podarek od nas dla wszystkich potomnych ${ }^{17}$. Tradycja rozumiana jest tutaj jako element scalający społeczeństwo oraz znak trwałości pewnych wartości, które jako wspólne dziedzictwo powinny być przekazane kolejnym pokoleniom. Dlatego tak trudne do zaakceptowania wydają się propozycje wprowadzania w niej jakichkolwiek zmian. Analizując ten aspekt, nietrudno dostrzec, że brak społecznego konsensusu w kwestii definiowania pojęcia tradycji był jednym z czynników utrudniających wzajemne porozumienie i rozwiązanie konfliktu.

Nie tylko pojęcie tradycji, ale również ona sama w postaci święta Sinterklaasa interpretowana była w odmienny sposób. Niektórzy zwolennicy zachowania jej dotychczasowej formy twierdzili na przykład, że Zwarte Pieten są czarni nie dlatego, iż mają czarny kolor skóry, lecz dlatego, że wchodząc do domów przez kominy, brudzą się sadzą ${ }^{18}$. Pogląd ten został dosłownie wyśmiany przez przeciwników, którzy zwracali uwagę na inne cechy negroidalne, takie jak fryzura afro, pogrubione usta i kolczyki w uszach oraz fakt, że Zwarte Pieten mają czarny kolor skóry już w momencie przybycia do Holandii, nie zaś po ukończeniu swojej „pracy”19.

Sprawa postaci Zwarte Piet nie nabrała silnego charakteru politycznego. Przedstawiciele rządu starali się zachować odpowiedni dystans, uważając, że rozwiązanie tej

\footnotetext{
${ }^{16}$ Zwarte Piet vraagt om een beetje begrip over en weer, "Het Parool", 11 X 2013.

17 Is Nederland gek geworden?, "De Telegraaf" 26 X 2013.

18 Alle kleuren zijn de sint even lief, "Het Parool", 26 X 2013.

19 Zwarte pijn en wit plezier, "de Volkskrant", 11 X 2013. Wywiad swobodny pozwolił ustalić, że nie był to jedynie pusty argument $w$ debacie, ale rzeczywiście funkcjonująca interpretacja tej tradycji.
} 
kwestii leży w gestii całego społeczeństwa. Wyjątek stanowiła postawa przedstawicieli skrajnie prawicowej partii PVV (Partij Voor de Vrijheid, lider: Gert Wilders) ${ }^{20}$. Ochrona „,pradawnych” tradycji holenderskich, które współtworzą narodową tożsamość, wpisuje się bardzo wyraźnie w jej politykę, ukierunkowaną na ochronę praw autochtonów, a także ograniczenie swobód imigrantów oraz obywateli pochodzących z dawnych kolonii.

Ważną funkcję w wyrażaniu stanowiska, ale także przyczynę zaostrzania się konfliktu, stanowił ton debaty, słyszalny nie tylko dosłownie w trakcie dyskusji toczących się w telewizji, lecz równie czytelny w opiniach wyrażanych w prasie oraz na forach internetowych. Używanie pojęcia rasizmu, niewolnictwa, nietolerancji, a także porównań do Holocaustu ${ }^{21}$, wzmacniało dodatkowo towarzyszące tej sprawie emocje. W pewnym momencie zauważono nawet, że rasizm nie tkwi w samych postaciach Zwarte Pieten, ale jest problemem społeczeństwa holenderskiego, ujawniającym się poprzez agresję stosowaną w debacie oraz brakiem skłonności do poszukiwania kompromisu. Przykładem najostrzejszych słów użytych podczas jednej z demonstracji oraz w mediach społecznych przez przeciwników wprowadzania zmian w tradycji jest następujący cytat: jak ci się nie podoba, wynoś się do swojego kraju²2 . Pojawiły się głosy, iż Holendrzy zrobili już wystarczająco dużo dla mniejszości zamieszkujących ich kraj i dlatego nie zamierzają w imię równości rezygnować ze swojej tradycji.

Debata miała również bardziej swobodne odsłony, charakteryzujące się zachowaniem dystansu i poczuciem humoru, będące w pewnym sensie balansem dla agresji i powagi sytuacji. Autorami tych opinii byli najczęściej czytelnicy dzienników. W kontekście rozważań na temat rasizmu ktoś pytał na przykład: Uważacie, że Sinterklaas jest rasistą, ponieważ pracują dla niego Zwarte Pieten? Rasizmem byłoby dopiero, gdyby ich teraz wszystkich pozwalniał, ponieważ są czarni ${ }^{23}$. Podobnym reakcjom warto przyjrzeć się na poziomie metarefleksji nad zaistniałym problemem. Są one wyrazem przypisywania całej sprawie mniej poważnego charakteru lub po prostu znużenia wszechobecnym i wciąż powracającym w mediach tematem. Holendrzy wzięli jednak bardzo liczny udział w debacie ${ }^{24}$, nawet jeśli swoje wypowiedzi rozpoczynali niejednokrotnie od wyrażenia niechęci wobec niej.

\footnotetext{
20 Een onschuldig, vrolijk volksfeest, "de Volkskrant", 22 X 2013.

${ }^{21}$ Zullen we weer gewoon gaan doen?, "NRC.NEXT", 25 X 2013.

22 Zwarte Piet hoort er nog steeds bij, Het Parool, 24 X 2013.

23 Een andere kleur, of is het allemaal gezeur?, "Trouw", 21 X 2013.

${ }^{24}$ Trudno jednoznacznie oszacować liczbę uczestników debaty. W dyskusjach internetowych brało udział od kilku do kilkunastu tysięcy internautów, petycję na Facebooku w obronie postaci Zwarte Piet podpisało w ciągu kilku dni około 1,5 miliona osób.
} 


\section{Tożsamość i identyfikacja. Opozycja: czarny - biały}

Jednym z głównych zarzutów - jak już wcześniej wspomniano - wysuwanych przez przeciwników tradycji świętego Mikołaja było wyraźne skojarzenie z niewolnictwem. Aspekt ten pozostaje istotną przyczyną napięć etnicznych, a nawet problemów wychowawczych związanych z funkcjonowaniem w społeczeństwie wieloetnicznym. Zwrócono uwagę na to, że coraz częściej metodą na uniknięcie tarć powodowanych wielokulturowością społeczeństwa jest stwarzanie pozorów nieistnienia różnych kolorów skóry ${ }^{25}$. Psycholodzy społeczni zauważyli, że ten swoisty daltonizm nie rozwiązuje problemu, ale jeszcze go nasila. Podkreślili, że w sytuacji, gdy kolor skóry staje się kulturowym tabu, rodzi się także ślepota na dyskryminację i nierówność ${ }^{26}$.

Konflikt ten dotyka zatem bezpośrednio pytania o tolerancję oraz jej granice w społeczeństwie wieloetnicznym. W swojej pracy o holenderskiej tolerancji Marcin Korzewski zauważył, że trwa ona tak długo, jak długo nie dotyka nikogo bezpośrednio (Korzewski, 2005, s. 10). Jego zdaniem holenderska tolerancja kształtowana jest przez dwie wartości: poczucie bezpieczeństwa oraz autonomii (niezależności, suwerenności). Obie wartości są istotne, ale ważniejsze okazuje się jednak bezpieczeństwo (Korzewski, 2005, s. 212-213). Tolerancja definiowana jest jako uznanie prawa innych do posiadania własnych poglądów. Możliwe są dwie postawy: akceptacja poglądów innych i uznanie ich za równoprawne z własnymi oraz ,znoszenie poglądów innych”, to znaczy akceptacja pomimo uznania ich za gorsze (Jakubowska-Branicka, 2010, s. 15). Problem z zaistnieniem tolerancji pojawia się w momencie, gdy uznanie poglądów (lub też uczuć) innych za równoprawne wyklucza zachowanie własnych poglądów. Zwolennicy Zwarte Pieten uznający prawo innych do negatywnych uczuć wywołanych przez tradycję, musieliby z niej zrezygnować. Przeciwnicy natomiast, dostrzegłszy wartość, jaką tradycja ta stanowi dla większości społeczeństwa holenderskiego, byliby zmuszeni wyrzec się swoich roszczeń. Dlatego tak trudne wydaje się osiągniecie w zaistniałym konflikcie konsensusu, który opierałby się na tolerancji rozumianej nie tylko jako uznanie odmienności, ale także na relatywizowaniu własnego absolutyzmu (Posern-Zieliński, 2004, s. 17).

Nie można jednak zanegować, że tolerancja postrzegana jest w Holandii jako cecha narodowa oraz element tożsamości. W debacie określona została jako narodowa duma

\footnotetext{
${ }^{25}$ Nu ligt de intolerantie tenminste op straat, "de Volkskrant", 25 X 2013.

${ }^{26}$ Warto także wspomnieć, że w trakcie toczącej się debaty w haskim Troppenmuseum otwarto wystawę poświęconą wzajemnym relacjom na przestrzeni stuleci pomiędzy białym i czarnym człowiekiem. Jest ona świadectwem zainteresowania tym jakże ważkim problemem historycznym i współczesnym.
} 
oraz element wizerunku²7. Dlatego też atak na tradycję i zarzut o rasizm spotykały się z tak gwałtownymi reakcjami. Pozostawały bowiem w sprzeczności ze sposobem, w jaki Holendrzy postrzegają samych siebie.

Zagadnienie tolerancji nabiera szczególnego znaczenia w kontekście multikulturalizmu. Wielokulturowość wiąże się z bezpośrednim sąsiedztwem i przenikaniem się różnorodnych wzorców (Nikitorowicz, 2000, s. 87). Cechą wielokulturowości jest także przynależność tych samych jednostek do dwóch lub więcej kręgów kulturowych. Takie zjawisko obserwować można w Holandii; obywatele tego kraju mają silną tożsamość etniczną i związani są z grupą, do której przynależą. Z drugiej strony są pełnoprawnymi obywatelami kraju zachodnioeuropejskiego. Najistotniejszą kwestią, będącą jedną z głównych przyczyn eskalacji konfliktu, jest wzajemne oddziaływanie na siebie kultur. W sytuacji, gdy stykają się one ze sobą bezpośrednio, a ich prawo do autonomicznych poglądów narusza prawa innych, trudna staje się wzajemna akceptacja odmiennych postaw.

\section{Holendrzy - nie(Holendrzy)}

Wielokrotnie posługiwano się określeniem pradawnej lub staroholenderskiej tradycji, której zazwyczaj towarzyszył zaimek dzierżawczy „nasza”. Trudno jest zanegować wyraźne przesłanie wypływające z tego związku pomiędzy trwaniem tradycji oraz przynależności do społeczeństwa holenderskiego. Przeciwnicy pojawili się w nim później i zagrażają jego trwałości wyrażającej się właśnie w tradycji. Wymowne stało się stwierdzenie, że tradycji zagraża nie ktoś z zewnątrz, ale ktoś, kto urodził się „,we własnym domu”28. Ten ktoś - w kontekście tej wypowiedzi - nie zostaje wykluczony, przynależy do „metaforycznego domu", ale pozostaje jednocześnie kimś odrębnym. Można tu dostrzec zjawisko, w którym tożsamość doświadczana jest poprzez poczucie inności wobec drugich jednostek (Łodziński, 2007, s. 29).

Warto zauważyć, że i wśród przeciwników istniejącej formy tradycji, i w gronie ich zwolenników znaleźli się zarówno obywatele holenderscy pochodzenia europejskiego, jak i przedstawiciele mniejszości etnicznych. Ten aspekt był widoczny w prasie, w której autorzy listów do redakcji wyraźnie podkreślali swoje pochodzenie ${ }^{29}$. Pokazał to także jeden z holenderskich talk show, w którym zwolenników i przeciwników posadzono po przeciwnych stronach telewizyjnego studia. Argumenty stosowane w dyskusji wprowa-

\footnotetext{
27 Urenlang zwijgen zij, tegen Piet, "NRC Handelsblad”, 18 XI 2013.

28150 jaar worstelen met,zwart' \& ,wit', "Trouw", 1 XI 2013.

${ }^{29} \mathrm{~W}$ obchodach świętego Mikołaja biorą również udział mniejszości etniczne i dla wielu ich przedstawicieli postać Zwarte Pieten nie stanowi problemu.
} 
dziły natomiast inne podziały, oparte przede wszystkim na kategoriach etniczności ${ }^{30}$. Wzmacniano je poprzez stosowanie opozycji: „,my” i ,,oni” lub „,nasza tradycja” oraz ,ich atak na nią". Przywiązanie do tradycji i przeciwstawianie się jakimkolwiek zmianom w jej obrębie zaczęło być postrzegane jako znak bycia ,„prawdziwym” Holendrem. Przeciwnicy natomiast traktowani byli niemal jak zdrajcy.

Spór o czarnych pomocników postawił całą tradycję świętego Mikołaja w stan zagrożenia. Podkreśla się, że w obliczu różnorodności, która prowadzi do konfliktów podstawowych wartości, rodzi się skłonność do zaostrzenia poczucia tożsamości. Wojciech Burszta wykazał, że w dobie globalizacji każda tożsamość czuje się zagrożona (Burszta 2004, s. 16). Wynikiem tego jest przerysowywanie odrębności, podkreślanie wyjątkowości własnej kultury oraz tworzenie się postaw bezwzględności i bezkompromisowości (Lalak, 2000, s. 80). W taki sposób odczytać można postawę Holendrów wobec ich tradycji. Święty Mikołaj postrzegany jako pradawne święto będące wspólną wartością, a jego niezmienność i zakorzenienie w historii są znakiem stałości oraz długiego trwania. Spór o tradycję potraktować można jako etap negocjowania tolerancji, to znaczy wyznaczania jej granic i szukania kompromisu (Posern-Zieliński, 2004, s. 25).

W pewnym momencie tocząca się debata została wzbogacona o elementy autorefleksji31. Ujawniła ona sposób, w jaki Holendrzy postrzegają samych siebie. Pojawiła się świadomość, że otwartość i tolerancyjność są mrzonką, a prawdziwe oblicze holenderskiego społeczeństwa ujawnia się w mającym miejsce sporze. Oburzenie i zażenowanie budziły zwłaszcza mocne słowa zwolenników tradycji, którzy sugerowali oponentom powrót do własnej ojczyzny. Niektórzy uważali natomiast za pozytywny fakt, że dzięki tym sporom odsłonięte zostało prawdziwe oblicze społeczeństwa holenderskiego, gdyż poznanie prawdy o sobie jest wyjściem do autorefleksji².

\section{Holenderska tradycja w kontekście międzynarodowym}

Mówiąc o międzynarodowym kontekście sporu o Zwarte Pieten, trzeba zwrócić uwagę przede wszystkim na reakcje Holendrów na płynące z zewnątrz zainteresowanie sprawą, w mniejszym zaś stopniu na treść opinii zagranicznej. Reakcje te są bowiem przejawem podjętej przez społeczeństwo refleksji oraz wyrazem namysłu nad funkcjonującymi w nim autostereotypami.

\footnotetext{
30 Emotioneel feest in multiculturele straat, "AD/Algemeen Dagblad", 31 X 2013.

31 Zwarte Piet hoort er nog steeds bij, "Het Parool", 21 X 2013.

${ }^{32} \mathrm{Nu}$ ligt de intolerantie tenminste op straat, "de Volkskrant", 25 X 2013.
} 
Istotną kwestią poruszoną w debacie było prawo do decydowania o własnej tradycji. Dotyczyła ona przede wszystkim faktu tworzenia komisji ONZ, która miała badać holenderskie święto, sugerując wprowadzenie zmian lub jego całkowitą likwidację. Za niewłaściwe uważano zwłaszcza to, że ktoś z zewnątrz, nie znający zupełnie obyczajów holenderskich, miałby decydować o ich przyszłości ${ }^{33}$. Opinia ta należała jednak zasadniczo do osób wykazujących brak skłonności do jakichkolwiek zmian w tradycji. Wyrażała zatem sprzeciw nie tyle wobec ingerencji zewnętrznej, lecz ingerencji w ogóle. W tym kontekście bardzo istotną rolę odegrała historia, a konkretnie dzieje niewolnictwa.

Uroczystość świętego Mikołaja zaliczono nie tylko do tradycji, lecz przypisano mu przynależność do kanonu wiary. Był to kolejny argument, w którym tkwiła krytyka ONZ. Wolność wiary - podkreślano - jest sprawą wewnętrzną Holandii i dlatego nie leży w gestii instytucji międzynarodowych ${ }^{34}$.

W kontekście międzynarodowym mieści się również fakt, że święto Sinterklaasa nie zostało dotąd wpisane na listę dziedzictwa niematerialnego UNESCO. Wywoływał on pewnego rodzaju napięcie pomiędzy obrońcami tradycji oraz światem nauki, do którego należał ten obowiązek. Uważano, iż w ten sposób udałoby się uniknąć zagrożenia likwidacją czy nawet konieczności wprowadzania zmian. Przedstawiciele środowiska naukowego wyjaśniali jednak, że podczas międzynarodowych spotkań postać Zwarte Pieten staje się zawsze tematem tabu oraz jest główną przyczyną tego, że właśnie to święto nie znajduje się na liście UNESCO ${ }^{35}$.

Przeciwnicy postaci Zwarte Pieten odwoływali się kilkakrotnie do reakcji płynących z zewnątrz oraz emocji, jakie budziły one pośród przedstawicieli innych narodów. $W$ jednym $z$ artykułów przytoczono relacje $z$ wizyty czarnoskórego pisarza amerykańskiego, który na widok pomocników świętego Mikołaja wyraził chęć jak najrychlejszego powrotu do domu ${ }^{36}$. Telewizja holenderska pokazała też sondę uliczną przeprowadzoną w Stanach Zjednoczonych, prezentując negatywne reakcje Amerykanów na fotografie Zwarte Pieten. Aspekt międzynarodowy obecny był zatem w autorefleksji dotyczącej wizerunku Holandii jako kraju tolerancyjnego, a przede wszystkim domagającego się tolerancji od innych, na przykład od Rosji. Postulowano, że pouczanie innych w kwestiach równości i przestrzegania praw człowieka powinno poprzedzić rozwiązanie własnego, wewnętrznego problemu ${ }^{37}$.

\footnotetext{
${ }^{33}$ Kamer eist uitleg VN-functionaris, "De Telegraaf", 25 X 2013.

${ }^{34}$ Kleurenpiet doet het net zo goed als Zwarte Piet, "de Volkskrant", 19 X 2013.

${ }^{35}$ Hou het hoofd koel in Pietendiscussie, "Spits", 24 X 2013.

${ }^{36}$ Hoe een soeverein land in de problemen kan komen, "De Telegraaf", 25 X 2013.

37 Voor haar huilende zusje, "NRC.NEXT", 28 X 2013.
} 


\section{Media}

Żyjemy w erze środków masowego przekazu, a te stwarzają podstawy wszelkich procesów: społecznych, politycznych i gospodarczych (Stadtmuller, 2003, s. 55). Media są głównym czynnikiem kształtującym opinię publiczną, ale także przestrzenią, w której wyrażane są własne poglądy. Interakcja zachodząca pomiędzy uczestnikami komunikacji przy użyciu mediów różni się diametralnie od kontaktu bezpośredniego. Media stwarzają większe poczucie swobody i dają możliwość wzięcia udziału w dyskusjach o znacznie szerszej tematyce. Ponadto dają możliwość autoprezentacji oraz wyrażania własnej tożsamości (Webb, Wilson, Hodges, Smith, Zakeri, 2012, s.4-5). Współczesne media są ze sobą zintegrowane, to znaczy, że zasięg przekazywanej informacji nie ogranicza się tylko do jednego z nich (Turow, 2011, s. 5). Debata wokół postaci Zwarte Pieten ujawniła tę zależność. Opinie powtarzane w prasie powtarzane były w Internecie, a dyskusja na Facebooku komentowana w dziennikach.

Za sprawą mediów i prasy spór o postać Zwarte Pieten nabrała ogromnego rozgłosu, wywołując bardzo silne emocje. Dyskusja nabierała impetu nie tyle za sprawą przeciwników, ile zwolenników tradycji. Ogromną rolę odegrała w niej szesnastolatka Mandy Roos, będąca inicjatorką powołania strony na Facebooku Zwarte Piet moet blijven (Zwarte Piet musi pozostać), mającej charakter petycji, „,podpisanej” następnie w ciągu dwóch dni przez około dwóch milionów osób. W ten sposób ujawniło się ogromne zainteresowanie społeczne zaistniałym sporem. Mandy Roos zorganizowała także w Hadze na Malieveld demonstrację przeciw wprowadzeniu zmian $w$ istniejącej tradycjij ${ }^{38}$.

Ponieważ dyskusja toczyła się na łamach prasy i w mediach społecznych, jej ton i kierunek wyznaczali z jednej strony dziennikarze i prezenterzy, z drugiej zaś zwykli obywatele. To do nich należał wybór nastroju nadawanego kolejnym odsłonom „dramatu”. Dziennikarze oddawali głos wielu osobom wywodzącym się z najróżniejszych środowisk. Słyszalne były opinie przedstawicieli środowisk naukowych, polityków, a także zwykłych ludzi. Forum wypowiedzi dla tych ostatnich stał się przede wszystkim Facebook, który w ostatnich latach zajmuje czołowe miejsce w komunikacji społecznej (Benjamin, 2012, s. 280-283). Optymistyczne stanowisko w teorii komunikacji zakłada bezpośredni dialog poprzez sieć (Michalczyk, 2006, s. 139). Wyrażane za pośrednictwem Facebooka opinie docierały do bardzo dużej grupy odbiorców i nie pozostawały anonimowe. Umożliwiał on także natychmiastową reakcję i wysunięcie kontrargumentów.

38 Blijf van Piet af!; Mandy roept Nederland op te demonstreren op Malieveld, "De Telegraaf", 24 X 2013. 
Jeśli w ten sposób rozumiane jest pojęcie dialogu, można zastosować je w odniesieniu do toczącej się w Holandii debaty. Facebook stał się z jednej strony miejscem wymiany opinii, z drugiej zaś stworzył dosyć niebezpieczną przestrzeń komunikacyjną, w której dochodziło do osobistych ataków. Ich obiektem stała się między innymi holenderska piosenkarka Anouk, po tym, jak na własnym profilu ujawniła swój sprzeciw w stosunku do postaci Zwarte Pieten. Opinie wyrażane za pomocą mediów charakteryzują się tym, iż nie podlegają cenzurze. Dlatego możliwe jest pojawienie się agresji, na którą często odpowiada kolejna jej fala.

\section{Podsumowanie}

Przedstawiona analiza studium przypadku służy przede wszystkim zwróceniu uwagi na konkretne zjawisko, a mianowicie na możliwość wystąpienia konfliktu o tradycję należącą do większości w wieloetnicznym społeczeństwie zachodnioeuropejskim. Jego cechą szczególną jest żądanie dostosowania się grupy autochtonicznej do „potrzeb” etnicznej mniejszości, której przedstawiciele są obywatelami kraju europejskiego, ale wciąż postrzegani są jako grupa imigracyjna.

Eskalację społecznego konfliktu dotyczącego postaci Zwarte Pieten powiązać można z omawianymi powyżej kwestiami: cechami komunikacji, napięciami istniejącymi w wieloetnicznym społeczeństwie zachodnim w dobie globalizacji, tożsamością i identyfikacją narodową Holendrów oraz rolą mediów. W procesie komunikacji dochodziło do swoistych nieporozumień, wynikających z braku jednolitego definiowania pojęć i postrzegania ważkich kwestii. Swoje znaczenie miało wprowadzenie do dyskursu bardzo negatywnie nacechowanych pojęć oraz przywoływanie trudnych momentów historycznych. Nie sposób było uniknąć powiązań z niewolnictwem, które stanowiło główny argument krytyków tradycji. Przywoływanie innych elementów historii, jak choćby Holocaustu, służyło natomiast wyłącznie wzmożeniu negatywnych emocji. Z nich rodziła się następnie agresja, która utrudniała porozumienie i uniemożliwiała podjęcie racjonalnej dyskusji.

Przyczyny eskalacji konfliktu dotyczącego tradycji tkwią głęboko w jej współczesnej kondycji oraz roli, jaką ona odgrywa w Holandii, zwłaszcza w realiach społeczeństwa wieloetnicznego oraz $\mathrm{w}$ dobie globalizacji prowadzącej do powstawania wielu tożsamości i zacierania się poczucia wspólnoty narodowej. Tocząca się debata ujawniła także tkwiące w społeczeństwie holenderskim nierozwiązane problemy kulturowe, które są w stanie uśpienia i „,wypływają” w sytuacji zagrożenia. W bezpośrednim związku z tymi 
kwestiami pozostaje relacja ze światem zewnętrznym, którego ingerencja postrzegana jest jako wtrącanie się w wewnętrzne sprawy Holandii.

Warto również jeszcze raz podkreślić, że już w trakcie trwania sporu podjęto zarówno autorefleksję dotyczącą samej debaty, jak i dysfunkcji społeczeństwa. Nie tylko środowisko naukowe wypowiadało się w tej kwestii, gdyż agresja pojawiająca się w mediach wywoływała społeczny sprzeciw. Refleksja o debacie stała się jej kontynuacją, rozszerzeniem problemów, których dotyczył właściwy konflikt. Zmuszała do namysłu nad jego szerszym kontekstem. Zanegowanie jednej z podstawowych wartości społeczeństwa holenderskiego, za którą uchodzi tolerancja, wzmacniało oburzenie i paradoksalnie prowadziło do aktów nietolerancji.

Wpływ na tak silną eskalację konfliktu miały również fora, na których toczyła się debata. Opinie wypowiadane w gronie rodziny lub przyjaciół mają niewielki zasięg oddziaływania. Uwagi pojawiające się w prasie oraz mediach społecznych dostępne są dla każdego. Facebook stwarza możliwość natychmiastowej reakcji, a każda indywidualna opinia może być skomentowana przez wszystkich uczestników dyskusji. Na eskalację konfliktu wpływa zatem słyszalność wszystkich głosów oraz łatwy dostęp do publicznego wyrażenia własnej opinii. Różnorodność argumentów prowadzi z kolei do zbaczania dyskusji z właściwego toru i tworzenia się wielu jej odłamów. Wprowadzanie pobocznych wątków utrudniało rozstrzygniecie najbardziej istotnego dylematu, jakim wydaje się napięcie społeczne i negatywne odczucia wywołane przez postaci Zwarte Pieten. Można odnieść wrażenie, że stosowane przez obie strony argumenty nie miały przekonać przeciwników, a jedynie wprowadzić chaos i oddalić moment rozwiązania problemu.

Tocząca się każdego roku debata ujawnia tarcia międzykulturowe w społeczeństwie holenderskim, które są obecne, ale nie zawsze słyszalne, pozostają zagłuszane albo ignorowane. Można uznać, że ma to aspekt pozytywny. Dostrzeżenie problemu może - chociaż nie musi - być punktem wyjścia do jego rozwiązania.

\section{Bibliografia:}

Al-Deen, H., Hendricks, J. (red.). (2012). Social media: usage and impact. Lanham: Lexington Books.

Bartz, B. (1997). Idea wielokulturowego wychowania w nowoczesnych społeczeństwach. Radom: Instytut Technologii Eksploatacji Duisburg.

Boer-Dirks, E., Helsloot, J. (2009). Het Sinterklaas boek. Zwolle: Wbooks.

Boer-Dirks, E. (1993). Nieuw licht op Zwarte Piet. Een kunsthistorisch antwoord op de vraag naar de herkomst van Zwarte Piet. Volkskundig Bulletin. Tijdschrift voor Nederlandse cultuurwetenschap, nr 19. s. 1-35. 
Booy, F. (2008). Op zoek naar Zwarte Piet. Een speurtocht naar de herkomst, de ontwikkeling en de betekenis van de dinaar van Sinterklaas. Eindhoven: Stichting Nationaal Sint Nicolaas Comité.

Booy, F. (2005). Zwarte Piet. Traditie, (zomer). s. 5-6.

Borden, G. (1996). Orientacja kulturowa. Teoria służąca rozumieniu i badaniom komunikacji międzykulturowej. W: A. Kapciak, L. Korporowicz, A. Tyszka (red.), Komunikacja międzykulturowa: zderzenia i spotkania. Warszawa: Instytut Kultury.

Burszta, W. (2004). Tolerancja w dyskursie antropologicznym. W: A. Posern-Zieliński (red.), Tolerancja i jej granice w relacjach międzykulturowych. Poznań: Wydawnictwo Poznańskie.

Ghesquiere, R. (1989). Van Nicolaas van Myra tot Sinterklaas. De kracht van een verhaal. Amersfoort: Davidfonds.

Helsloot, J. (2008). De ambivalente betekenis van de eerste 'Zwarte Piet'. W: E. Doelman, J. Helsloot (red.), De kleine Olympus. Over enkele figuren uit de alledagse mythologie (s. 93-117). Amsterdam: Aksant Academic Publishers.

Helsloot, J. (2001). De opkomst van Sinterklaas als nationaal feest in Nederland. Eeen schets op grond van twee volkskundevragenlijsten (1943 en 1994) van het Meertens Instituut. W: A. Döring (red.), Faszination Nikolaus, Kult, Brauch und Kommerz (s. 104-139). Essen: Klartext-Verlagsges.

Helsloot, J. (2005). De strijd van Zwarte Piet. W: I. Holving, H. Dibbits, M. Schrover (red.), Veranderingen van het alledaagse 1950-2000 (s. 249-271). Den Haag: Sdu.

Helsloot, J. (2009). Is Zwarte Piet uit te leggen?. W: W. Koops, M. Pieper, E. Boer (red.), Sinterklaas verklaard (s. 76-85). Amsterdam: SWP.

Helsloot, J. (2003). Sinterklaas - altijd anders. W: R. Njssen (red.), Sint-Nicolaas Genootschap Nederland 1993-2003 (s. 96-103). Rotterdam: Sint Nicolaasgenootschap,.

Jacher, W. (2007). Tożsamość i wielokulturowość jako kategorie badań. W: M. Korzeniowski, A. Barska (red.), Wielokulturowość - Międzykulturowość - Transkulturowość w perspektywie europejskiej i pozaeuropejskiej. Opole: Uniwersytet Opolski.

Korzewski, M. (2005). O tolerancji w społeczeństwie i prawie holenderskim. Kraków: Nomos. Krzysztofek, K. (2010). Tolerancja i nietolerancja: kilka pytań i hipotez badawczych. W: I. Jakubowska-Branicka (red.), O tolerancji we współczesnej demokracji liberalnej. Warszawa: Trio. Kuciński, M. (2011). Różnorodność kultur a tożsamość człowieka w zglobalizowanym świecie. W: H. Czakowska, M. Kuciński (red.), Dialog kultur, cywilizacji i religii. Bydgoszcz: KPSW.

Lalak, D. (2000). Różnice społeczne - niszczą czy budują?. W: T. Pilch (red.), O potrzebie dialogu kultur i ludzi. Warszawa: ŻAK Wydawnictwo Akademickie.

Langeler, A. (1994). Zwarte Piet. Amsterdam: Jan Mets.

Łodziński, S. (2007). Wielokulturowość i prawa mniejszości. Zmieniające się wizje integracji imigrantów w Europie. W: M. Korzeniowski, A. Barska (red.), Wielokulturowość - Międzykulturowość - Transkulturowość w perspektywie europejskiej i pozaeuropejskiej. Opole: Uniwersytet Opolski.

Michalczyk, S. (2006). Demokracja medialna: między wizją a rzeczywistością. W: S. Michalczyk (red.), Media i komunikowanie w społeczeństwie demokratycznym. Szkice medioznawcze. Sosnowiec: Wyższa Szkoła Humanitas.

Nikitorowicz, J. (2010). Grupy etniczne w wielokulturowym świecie. Sopot: GWP. 
Nikitorowicz, J. (2000). Spotkanie i dialog kultur - wymiar edukacji międzykulturowej. W: T. Pilch (red.), O potrzebie dialogu kultur i ludzi. Warszawa: ŻAK Wydawnictwo Akademickie.

Nikitorowicz, J. (2003). Wartości etosu jako podstawa kształtowania tożsamości wielokulturowej, podłoże konfliktów kulturowych i cel edukacji międzykulturowej. W: T. Lewowicki, E. Ogrodzka-Mazur, A. Gajdzica (red.), Świat wartości i edukacja międzykulturowa. Cieszyn-Warszawa: Wydawanictwo Uniwersytetu Śląskiego.

Ociepka, B. (2003). Komunikacyjne ścieżki globalizacji. W: E. Stadmuller (red.), Wkraczając w XXI wiek. Między globalizacją a zróżnicowaniem. Wrocław: Arboretum.

Odé, A. (2008). Etnische minderheiden in Nederland. W: Jaarboek multiculturele samenleving in ontwikkeling, feiten \& cijfers, feestdagen \& adressen. Den Haag: Sdu.

Posern-Zieliński, A. (2004). Negocjowanie tolerancji, czyli między groźbą konfliktu a dążeniem do współdziałania. W: A. Posern-Zieliński (red.), Tolerancja i jej granice w relacjach międzykulturowych. Poznań: Wydawnictwo Poznańskie.

Smolicz, J. (1990). Kultura i nauczanie w społeczeństwie wieloetnicznym. Warszawa: Państwowe Wydawnictwo Naukowe.

Trutkowski, C. (2004). Wybór czy konieczność - wykorzystanie analizy dyskursu w socjologii, „Kultura i Społeczeństwo”, 1/2004, s. 35-50.

Turow, J. (2011). Media today: an introduction to mass communication. Nowy Jork: Routledge. Van Leer, M. (1995). Geven rond Sinterklaas. Een ritueel als spigel van veranderende relaties. Amsterdam: Het Spinhuis.

Winiarski, M. (2000). Znaczenie i wymiary dialogu międzyludzkiego. W: T. Pilch (red.), O potrzebie dialogu kultur i ludzi. Warszawa: ŻAK Wydawnictwo Akademickie.

Wouters M.-J. (2008). Sinterklaas lexicon. Sinterklaas van A tot Z. Haarlem: Becht.

\section{Summary:}

This paper examines the public debate about Dutch tradition of Sinterklaas (Saint-Nicolas) and particularly the character of Zwarte Piet, the black-faced helper. His apparent racist nature has been subject of debate in Dutch media for years. However, in 2013 the debate escalated and provoked social conflicts and verbal aggression. The paper gives some explanations why this happened. The case of Zwarte Piet is noteworthy because it shows that Dutch society, well-known for being tolerant and open-minded, is not entirely free of ethnic and national tensions. This Old Dutch tradition that had been shaped in the times of colonialism and slavery, has become a hot issue in todays' multicultural society. The paper includes considerations concerning the emergence of social conflicts and the meaning of postmodern national and ethnic identity. Additionally, it discusses the role of social media in fuelling the debate. Conclusions are based on analysis of social media content (television, Internet) and publications in the Dutch press from October to December 2013.

\section{Keywords:}

The Netherlands, tradition, folklore, multi-ethnic society, racism 


\section{Streszczenie:}

Artykuł dotyczy debaty społecznej toczącej się wokół holenderskiej tradycji Sinterklaasa (świętego Mikołaja), a szczególnie wokół postaci Zwarte Piet - pomocnika z uszminkowaną na czarno twarzą. Jego wyraźnie negroidalny wygląd rodzi oskarżenia o rasizm i dlatego od wielu już lat wywołuje dyskusje w holenderskich mediach. W roku 2013 miała miejsce szczególnie ostra dyskusja, która prowadziła do konfliktów oraz agresji słownej. W artykule podjęto próbę wyjaśnienia przyczyny tej sytuacji. Problem postaci Zwarte Piet jest godny uwagi, ponieważ pokazuje, że społeczeństwo holenderskie, uchodzące za tolerancyjne i otwarte, nie jest całkowicie wolne od napięć o charakterze etnicznym i narodowym. Dawna holenderska tradycja, która ukształtowała się w czasach kolonializmu i niewolnictwa, stała się poważnym problemem we współczesnym wielokulturowym społeczeństwie. Artykuł zawiera rozważania na temat powstawania konfliktów społecznych oraz nowoczesnej świadomości etnicznej i narodowej. Ponadto porusza zagadnienie roli mediów w zaostrzaniu dyskusji i towarzyszącej jej agresji. Wnioski zostały oparte na analizie treści medialnych (telewizja, internet) oraz artykułów prasowych, które pojawiały się od października do grudnia 2013 roku.

\section{Słowa kluczowe:}

Holandia, tradycja, folklor, społeczeństwo wieloetniczne, rasizm 